\title{
Sepiolite-based adsorbents for carbon dioxide capture
}

\author{
Alicja Szymańska*, Karolina Kiełbasa \\ West Pomeranian University of Technology, Szczecin, Faculty of Chemical Technology and Engineering, Department of \\ Catalytic and Sorbent Materials Engineering, Piastów Ave. 42, 71-065 Szczecin, Poland \\ "Corresponding author: e-mail: alicja.szymanska@zut.edu.pl
}

\begin{abstract}
Sepiolite and the sepiolite-based materials were studied in terms of carbon dioxide adsorption. The pore structure and the surface characterization of the obtained materials were specified based on adsorption-desorption isotherms of nitrogen measured at $-196^{\circ} \mathrm{C}$ and carbon dioxide at $0^{\circ} \mathrm{C}$. The specific surface area (SSA) was calculated according to the BET equation. The pore volume was estimated using the DFT method. Pristine sepiolite has shown the following value of SSA and $\mathrm{CO}_{2}$ uptake at $0^{\circ} \mathrm{C}-105 \mathrm{~m}^{2} / \mathrm{g}$ and $0.27 \mathrm{mmol} / \mathrm{g}$, respectively. The highest value of these parameters was found for material obtained by $\mathrm{KOH}$ activation of mixture sepiolite and molasses (MSEP2) $-676 \mathrm{~m}^{2} / \mathrm{g}$ and $1.49 \mathrm{mmol} / \mathrm{g}$. Sample MSEP2 also indicated the highest value of total pore volume and micropores volume with a diameter up to $0.8 \mathrm{~nm}$.
\end{abstract}

Keywords: sepiolite, molasses, carbon-clay composite, $\mathrm{CO}_{2}$ adsorption.

\section{INTRODUCTION}

Carbon dioxide makes up the vast majority of greenhouse gas emissions $(81 \%)$ but smaller amounts of methane $(10 \%)$, nitrous oxide $(6 \%)$ and fluorinated gases (3\%) are also emitted ${ }^{1}$. Absorption of $\mathrm{CO}_{2}$ from flue gas by amine scrubbing is a traditional method and currently in operation. The amine solution has some disadvantages such as high volatility, low thermal stability, and high oxidation degradation ${ }^{2}$.

Adsorption is a promising alternative method for $\mathrm{CO}_{2}$ capturing and could replace an amine-based absorption technique ${ }^{3}$. Zeolites ${ }^{4,5}$, carbon-based materials ${ }^{6-9}$ and metal-organic frameworks ${ }^{10-12}$ are the most critical class of adsorbents actively investigated for gas adsorption applications. Unfortunately, the moisture typically present in the flue gas stream affects zeolites and metal-organic frameworks structural stability ${ }^{13}$. Carbon materials, exhibit better stability towards moisture and also against corrosive gases ${ }^{14}$. Because of high adsorption capacity, easy availability and low cost activated carbons are most commonly tested as $\mathrm{CO}_{2}$ adsorbents, ${ }^{65-17}$. A variety of carbonaceous adsorbents were also considered for $\mathrm{CO}_{2}$ capture: carbon nanotubes ${ }^{9}$, carbon spheres ${ }^{18}$, nitrogen-doped nanoporous carbon ${ }^{19}$, porous carbon nanosheets ${ }^{20}$. There are also attempts to convert $\mathrm{CO}_{2}$ into valuable products such as methane ${ }^{21}$, formaldehyde ${ }^{22}$, methanol ${ }^{23}$.

Methane is emitted from energy, industry, agriculture, and waste management activities. $\mathrm{CH}_{4}$ lifetime in the atmosphere is much shorter than $\mathrm{CO}_{2}$, but $\mathrm{CH}_{4}$ is more effective at trapping radiation than $\mathrm{CO}_{2}$. The comparative impact of $\mathrm{CH}_{4}$ is 25 times greater than $\mathrm{CO}_{2}$ over a 100 years $^{24}$. The most significant industrial methane-based process is methane steam reforming to syngas - a mixture of $\mathrm{CO}$ and $\mathrm{H}_{2}$. The dry reforming of methane was also investigated ${ }^{25,26}$.

Converting methane to alternative forms sources of energy, such as methanol ${ }^{27,28}$, formaldehyde ${ }^{29,30}$ and other derivatives ${ }^{31-34}$ is a preferred method for methane reduction. Catalytic methane decomposition led to the production of pure hydrogen and carbon nanomaterials $^{35-38}$. Methane can be applied as vehicle fuel ${ }^{39,40}$.

Carbonaceous materials are right sorbents for other gases and vapors, e.g. hydrogen ${ }^{41-43}$. They were also described as catalysts and catalysts supports ${ }^{44-46}$.
Clays are hydrated aluminum phyllosilicates naturally formed through hydrothermal alteration of rocks. Clay minerals have a sheet-like structure and are composed of mainly tetrahedral silicate and octahedral hydroxide groups $^{47}$.

Sepiolite, formerly known as Meerschaum (sea froth), is a naturally occurring phyllosilicate clay mineral, that is widespread due to its unusual fibrous morphology and intracrystalline tunnels. The main advantages of sepiolite are the porosity, the fibrous structure, the fine grain size, and the high surface area, which make it a valuable material for a wide range of applications (e.g. pesticide and catalyst carrier, decolourizing and anticaking agents or pharmaceutical and cosmetics applications $)^{48,49}$.

Due to their low price, abundance, and porosity, clay materials (as montmorillonite, kaolinite, and bentonite) have been used as supports for $\mathrm{CO}_{2}$ adsorption ${ }^{50-52}$. However, to the best of our knowledge, the carbon dioxide adsorption of sepiolite-based materials (sepiolite-carbon composites from biomass) has not yet been reported.

\section{EXPERIMENTAL}

\section{Preparation of sepiolite-based adsorbents}

The sepiolite (SEP) was mixed with potassium hydroxide $(\mathrm{KOH})$ in a ratio of 1:1 (KSEP), potassium hydroxide and molasses in a ratio of 1:1:1 (MSEP1) and in a ratio of 1:2:1 (MSEP2) and left in the room temperature for three hours. Afterward, samples KSEP, MSEP1, and MSEP2 were dried at $200^{\circ} \mathrm{C}$ for $19 \mathrm{~h}$. In the next step, the materials were exposed to $800^{\circ} \mathrm{C}$ in a furnace for $1 \mathrm{~h}$ under a constant nitrogen flow $18 \mathrm{dm}^{3} / \mathrm{h}$. After that time, obtained materials were washed with the deionized water to a $\mathrm{pH}$ value of 6.5 to remove $\mathrm{KOH}$. Then, the materials were soaked in hydrochloric acid $(\mathrm{HCl})$ in a concentration of $1 \mathrm{~mol} / \mathrm{dm}^{3}$ for $19 \mathrm{~h}$, washed again with the deionized water until the $\mathrm{pH}$ of filtrate became 6.5 and dried at $200^{\circ} \mathrm{C}$ for $12 \mathrm{~h}$.

The sepiolite (SEP) was also mixed with potassium hydroxide $(\mathrm{KOH})$ in a ratio of 1:1 and left in the room temperature for three hours, but the heating step (to $800^{\circ} \mathrm{C}$ ) was omitted (ISEP). The rest of the preparation stage was the same as for the samples mentioned above. 


\section{Characterization of sepiolite and sepiolite-based adsor- bents}

Sepiolite and sepiolite-based adsorbents were characterized by nitrogen adsorption-desorption isotherms measured at $-196^{\circ} \mathrm{C}$ using Quantochrome Autosorb Instrument. Before analysis, all the samples were outgassed at $250^{\circ} \mathrm{C}$ under vacuum for $16 \mathrm{~h}$ in a vacuum environment. The specific surface area (SSA) was estimated from the adsorption isotherm using the standard Brunauer-Emmett-Teller (BET) equation based on adsorption data. The micropore volume $\left(\mathrm{MPV}_{\mathrm{N} 2}, \mathrm{MPV}_{\mathrm{CO} 2}\right)$ was assessed by the Density Functional Theory (DFT) method used to the nitrogen and carbon dioxide adsorption. The total pore volume (TPV) was calculated based on the volume of $\mathrm{N}_{2}$ adsorbed at a relative pressure $\mathrm{p} / \mathrm{p}_{0}$ $\sim 1$. The DFT was also used to establish the pore size distributions (PSD) from sorption isotherms of nitrogen at $-196^{\circ} \mathrm{C}\left(\mathrm{PSD}_{\mathrm{N} 2}\right)$ and carbon dioxide at $0^{\circ} \mathrm{C}\left(\mathrm{PSD}_{\mathrm{CO} 2}\right)$.

The $\mathrm{CO}_{2}$ adsorption capacity at $0^{\circ} \mathrm{C}$ and $25^{\circ} \mathrm{C}$ were determined using the Quantachrome Autosorb Instrument.

$\mathrm{X}$-ray diffraction patterns of products were acquired by using PANalytical X'Pert PRO diffractometer. Data were collected over a $2 \theta$ range of $5 \div 80^{\circ}$ using $\mathrm{CuKa}$ radiation.

The morphology and elemental composition of products were examined by scanning electron microscopy (SEM). SEM images were performed using SU8020 (Hitachi) microscope with an accelerating voltage of about $15 \mathrm{kV}$ at 5000x magnification.

\section{RESULTS AND DISCUSSION}

Figure 1 presents nitrogen adsorption-desorption isotherms of obtained materials. Physisorption isotherms of all samples represent combination of type I and IV with a hysteresis loop of type H3 (for SEP, ISEP, and MSEP2) and H4 (for KEP, MSEP1), according to the IUPAC classification. The type I/IV isotherms showed that both, micropores and mesopores had been identified in samples. Capillary condensation in the pores occurred at a relative pressure $\left(\mathrm{p} / \mathrm{p}_{0}\right)$ above 0.40 , the most probably due to the presence of a large amount of narrow slit-like mesopores.

The textural properties (BET surface area, total pore volume, micropore volume) of sepiolite and sepiolitebased adsorbents are listed in Table 1 . The specific surface

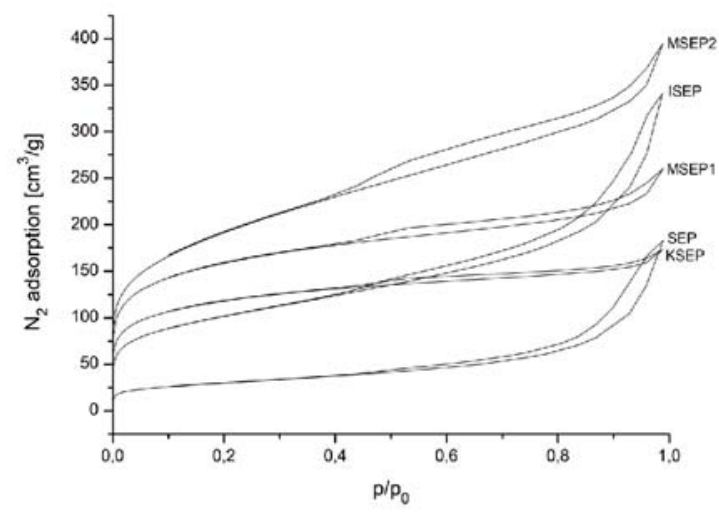

Figure 1. Nitrogen adsorption-desorption isotherms of pristine sepiolite and sepiolite-based materials
Table 1. Textural properties of pristine sepiolite and sepiolite-based materials

\begin{tabular}{|l|c|c|c|c|}
\hline Sample & $\begin{array}{c}\mathrm{SSA} \\
{\left[\mathrm{m}^{2} / \mathrm{g}\right]}\end{array}$ & $\begin{array}{c}\mathrm{MPV}_{\mathrm{CO} 2} \\
{\left[\mathrm{~cm}^{3} / \mathrm{g}\right]}\end{array}$ & $\begin{array}{c}\mathrm{MPV}_{\mathrm{N} 2} \\
{\left[\mathrm{~cm}^{3} / \mathrm{g}\right]}\end{array}$ & $\begin{array}{c}\mathrm{TPV} \\
{\left[\mathrm{cm}^{3} / \mathrm{g}\right]}\end{array}$ \\
\hline SEP & 105 & 0.017 & 0.008 & 0.285 \\
\hline ISEP & 351 & 0.069 & 0.044 & 0.530 \\
\hline MSEP1 & 570 & 0.107 & 0.119 & 0.403 \\
\hline MSEP2 & 676 & 0.113 & 0.086 & 0.613 \\
\hline KSEP & 426 & 0.101 & 0.003 & 0.269 \\
\hline
\end{tabular}

area of the materials increased following the chemical modifications. The highest surface area of $676 \mathrm{~m}^{2} / \mathrm{g}$ was achieved by $\mathrm{KOH}$ activation of mixture sepiolite and molasses (MSEP2). The other samples had a smaller BET surface area compared to MSEP2, but larger than pristine sepiolite. As presented in Table 1 the pores of examined materials exhibited a considerable increase in volume in comparison with sepiolite. In the case of sepiolite, the $\mathrm{KOH}$ treatment improves the porosity of sepiolite itself. The highest total pore volume was also achieved on sample MSEP2 $-0.61 \mathrm{~cm}^{3} / \mathrm{g}$. This sample also had the highest $\mathrm{MPV}_{\mathrm{CO} 2}$ value $-0.11 \mathrm{~cm}^{3} / \mathrm{g}$ (as well as sample MSEP1). However, the highest value of $\mathrm{MPV}_{\mathrm{N} 2}$ was found for sample MSEP1 $-0.12 \mathrm{~cm}^{3} / \mathrm{g}$. These values are much higher than those obtained for the pristine sepiolite.

Figure 2. shows the pore size distribution determined from $\mathrm{CO}_{2}$ adsorption isotherms at $0^{\circ} \mathrm{C}\left(\mathrm{PSD}_{\mathrm{CO} 2}\right)$, and Figure 3. reveals the results of PSD calculated from $\mathrm{N}_{2}$ adsorption isotherms at $-196^{\circ} \mathrm{C}\left(\mathrm{PSD}_{\mathrm{N} 2}\right)$. Both PSDs were calculated by the DFT method. To clarity the graph, the maximum value of the horizontal axis is $20 \mathrm{~nm}$, for the reason that the obtained materials did not contain a high number of larger pores. All the samples exhibited contents of pores with a diameter range of $0.3-20 \mathrm{~nm}$. The largest volume was occupied by pores with diameters ranging from 0.4 to $0.8 \mathrm{~nm}$ and 1.3 to $2.7 \mathrm{~nm}$, which confirms
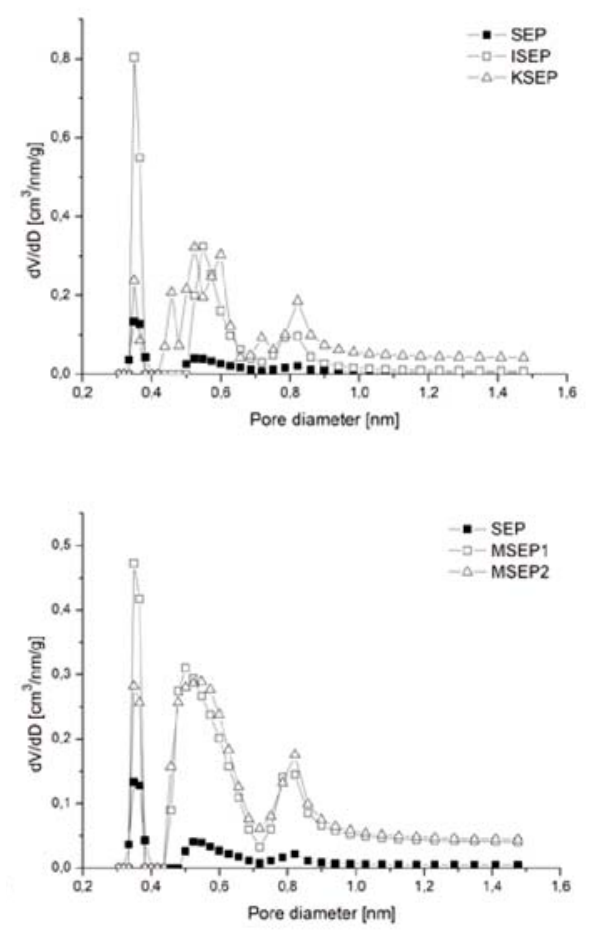

Figure 2. The pore size distributions of pristine sepiolite and obtained materials calculated from $\mathrm{CO}_{2}$ adsorption isotherms ( $\mathrm{D}$ - pores diameter) 

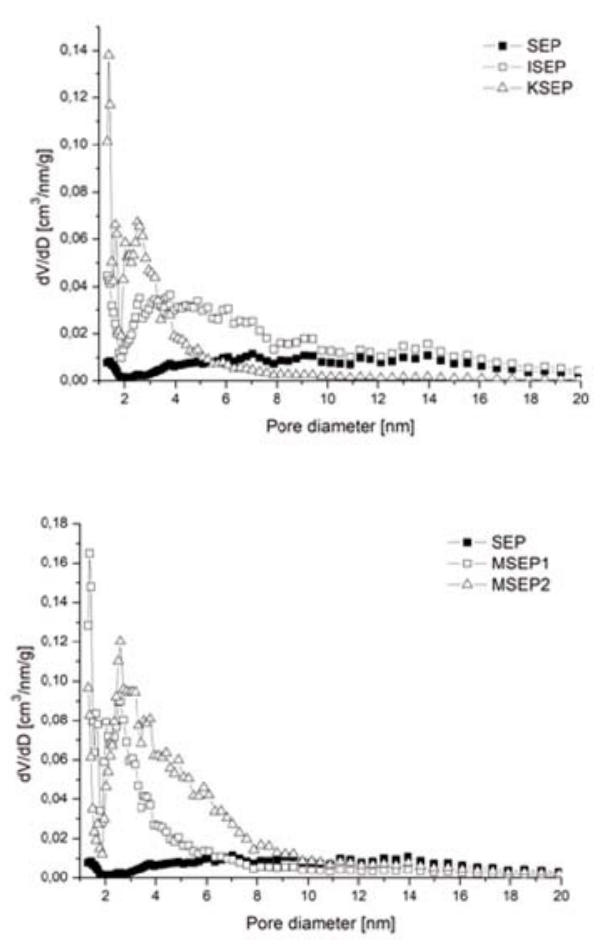

Figure 3. The pore size distributions of pristine sepiolite and obtained materials calculated from $\mathrm{N}_{2}$ adsorption isotherms ( $\mathrm{D}$ - pores diameter)

the development of microporosity and the presence of smaller mesopores in obtained materials.

The carbon dioxide adsorption isotherms of the examined samples are presented in Figure $4\left(\right.$ at $\left.0^{\circ} \mathrm{C}\right)$ and Figure $5\left(\right.$ at $\left.25^{\circ} \mathrm{C}\right)$. The $\mathrm{CO}_{2}$ uptake at 1 bar and $0^{\circ} \mathrm{C}$ is in the range of 1.18 to $1.49 \mathrm{mmol} / \mathrm{g}$, while for pristine sepiolite is $0.27 \mathrm{mmol} / \mathrm{g}$. In the case of $\mathrm{CO}_{2}$ uptake at 1 bar and $25^{\circ} \mathrm{C}$ is between 0.63 and $0.89 \mathrm{mmol} / \mathrm{g}$ for sepiolite-based materials and $0.18 \mathrm{mmol} / \mathrm{g}$ for pristine sepiolite. The highest value of $\mathrm{CO}_{2}$ capacity at $0^{\circ} \mathrm{C}$ and $25^{\circ} \mathrm{C}, 1.49 \mathrm{mmol} / \mathrm{g}$, and $0.89 \mathrm{mmol} / \mathrm{g}$ was confirmed for MSEP2 material.

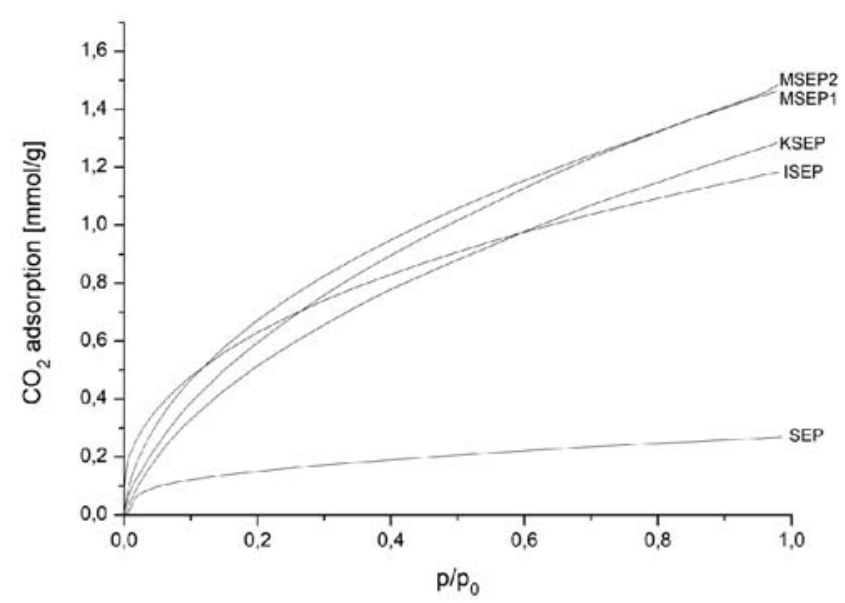

Figure 4. Carbon dioxide adsorption isotherms at $0^{\circ} \mathrm{C}$ of pristine sepiolite and sepiolite-based materials

Figure 6 demonstrates the relationship between specific surface area and carbon dioxide adsorption $\left(\right.$ at $\left.0^{\circ} \mathrm{C}\right)$, while Figure 7 presents the correlation between $\mathrm{MPV}_{\mathrm{CO} 2}$ value and $\mathrm{CO}_{2}$ uptake (also at $0^{\circ} \mathrm{C}$ ). It can be seen, that there is a excellent correlation between specific surface

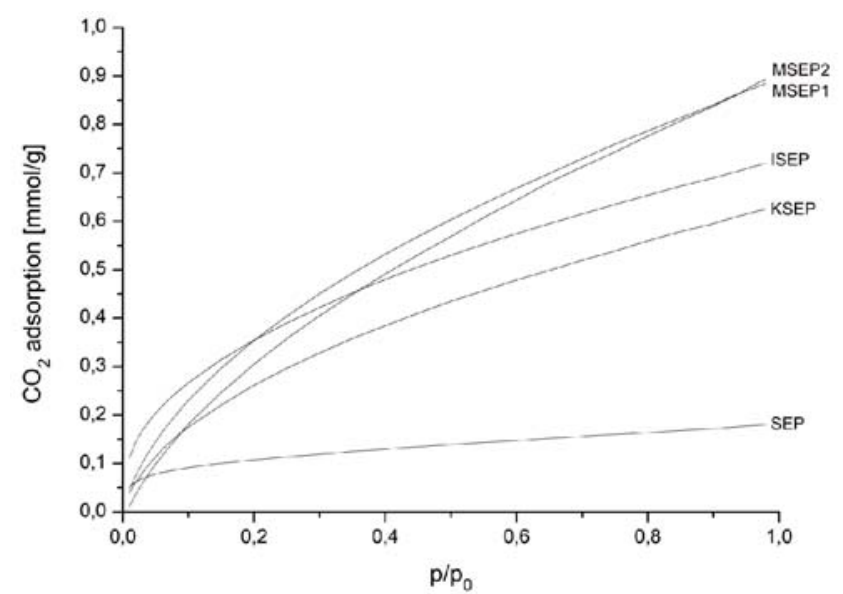

Figure 5. Carbon dioxide adsorption isotherms at $25^{\circ} \mathrm{C}$ of pristine sepiolite and sepiolite-based materials

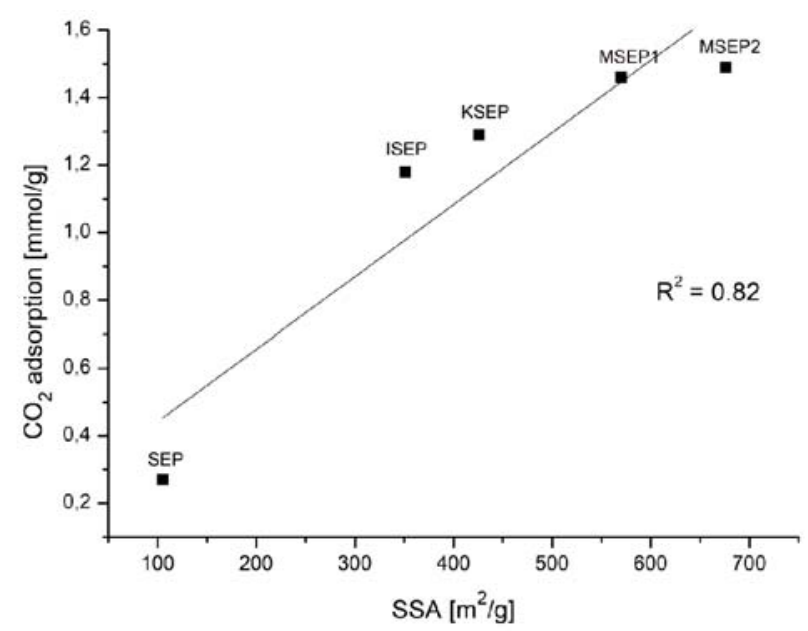

Figure 6. The correlation between SSA and $\mathrm{CO}_{2}$ adsorption $\left(\right.$ at $0^{\circ} \mathrm{C}$ ) for pristine sepiolite and obtained materials

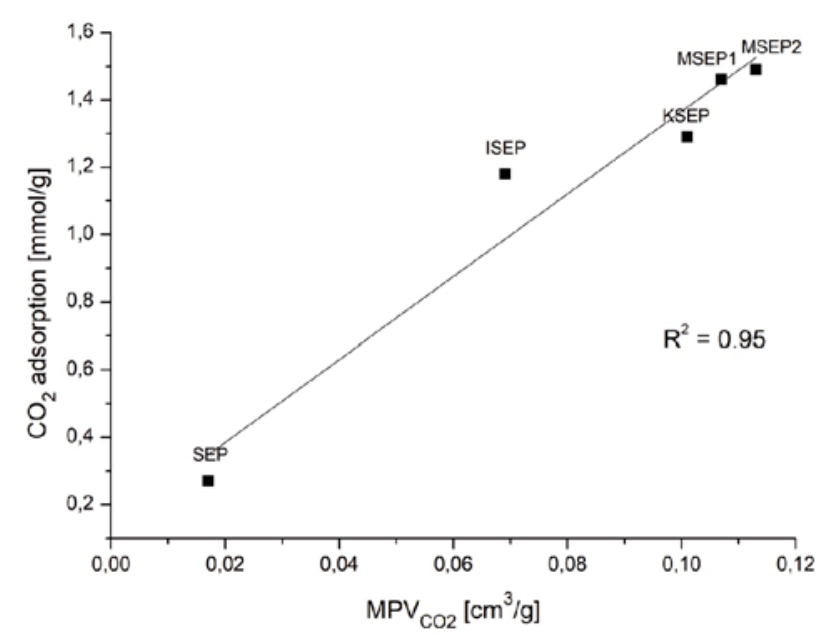

Figure 7. The correlation between $\mathrm{MPV}_{\mathrm{CO} 2}$ and $\mathrm{CO}_{2}$ adsorption $\left(\right.$ at $0^{\circ} \mathrm{C}$ ) for pristine sepiolite and obtained materials

area and micropore volume with $\mathrm{CO}_{2}$ uptake. It is, equal with other findings for micro- or mesoporous materials. The coefficient of determination $\left(\mathrm{R}^{2}\right)$ in both cases was high and amounted to -0.82 and 0.95 , respectively.

The XRD patterns of the pristine sepiolite and sepiolite-based materials were shown in Figure 8. For SEP, a diffraction peak with high intensity at $2 \theta=7.2^{\circ}$ was 


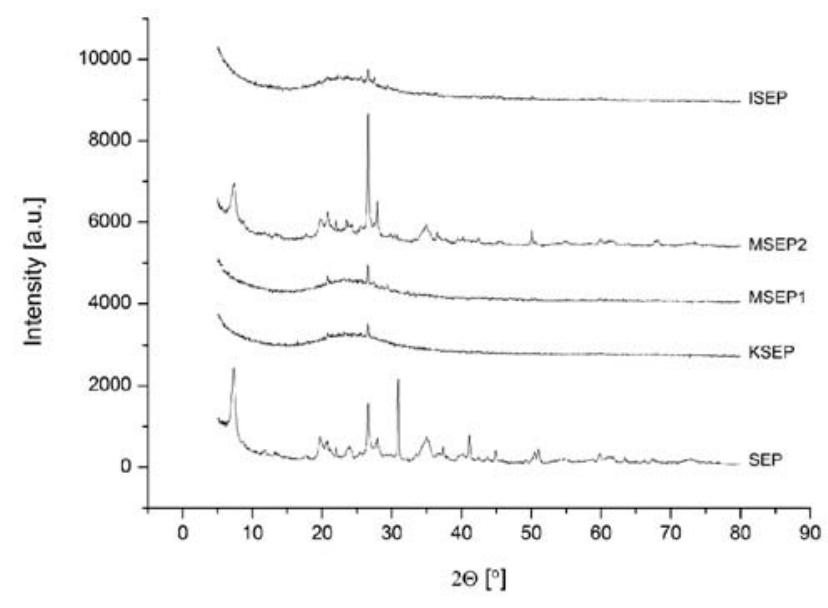

Figure 8. X-ray diffraction patterns of pristine sepiolite and obtained materials

ascribed to the (110) reflection of the sepiolite framework, which is the characteristic peak of sepiolite itself ${ }^{33,54}$. After impregnation with $\mathrm{KOH}$, there is no characteristic peak in patterns of ISEP, KSEP, and MSEP1 samples, indicating that the $\mathrm{KOH}$ treatment entirely changes the crystalline structure of sepiolite. In the case of MSEP2 material, the crystal structure was slightly changed, and the characteristic peak of sepiolite has been preserved.

The morphology of the examined materials was investigated by SEM, and typical SEM images are shown in Figure 9. It is well known that pore structure development is influenced by many factors, including inorganic impurities and the initial structure. The pristine sepiolite has fibrous morphology in the form of aggregates and some single fibers (Fig. 9a). After $\mathrm{KOH}$ treatment and pyrolysis (KSEP), the morphology seems to be similar. However, some single fibers were gone, and fibrous clusters appeared, as shown in Figure 9b. In the case of samples with molasses (MSEP1, MSEP2), changes in the structure of sepiolite can be observed. The materials MSP1 and MSP2 show an irregular shape and larger cavities compared with the pristine sepiolite (Fig. 9c, 9d).

\section{CONCLUSIONS}

Sepiolite-based materials have been prepared by $\mathrm{KOH}$ impregnation (ISEP), $\mathrm{KOH}$ impregnation in combination with the pyrolysis (KSEP), and $\mathrm{KOH}$ impregnation with the pyrolysis of sepiolite/molasses mixture (MSEP1, MSEP2). The results of structure characterization results showed the increased specific surface area and pore volume of obtained materials in comparison with pristine sepiolite. The surface treatment changed the porous structure of the pristine sepiolite. For SEP, the SSA, TPV, and $\mathrm{MPV}_{\mathrm{CO} 2}$ value was $105 \mathrm{~m}^{2} / \mathrm{g}, 0.285 \mathrm{~cm}^{3} / \mathrm{g}$, and 0.017 $\mathrm{cm}^{3} / \mathrm{g}$. The highest value of these parameters was obtained for MSEP2 $-676 \mathrm{~m}^{2} / \mathrm{g}, 0.613 \mathrm{~cm}^{3} / \mathrm{g}$, and $0.113 \mathrm{~cm}^{3} / \mathrm{g}$, respectively. Carbon dioxide adsorption tests showed that impregnating the pristine sepiolite with potassium hydroxide significantly improved $\mathrm{CO}_{2}$ adsorption capacity at $0^{\circ} \mathrm{C}$ and $25^{\circ} \mathrm{C}$. The highest value of $\mathrm{CO}_{2}$ capacity at $0^{\circ} \mathrm{C}$ and $25^{\circ} \mathrm{C}$ was obtained for MSEP2 material -1.49 $\mathrm{mmol} / \mathrm{g}$, and $0.89 \mathrm{mmol} / \mathrm{g}$, respectively. The sepiolite as a clay mineral is an inexpensive material, with abundant availability around the world. Moreover, it is vulnerable to chemical modification. Thus, the sepiolite treatment by potassium hydroxide, causing the increase of both - the microporosity and the $\mathrm{CO}_{2}$ adsorption capacity.

\section{LITERATURE CITED}

1. United States Environmental Protection Agency USEPA (2019). Greenhouse Gas Emissions. Retrieved May 26, 2020, from https://www.epa.gov/ghgemissions/overview-greenhousegases\#carbon-dioxide.

2. Parshetti, G.K., Chowdhury, S. \& Balasubramanian, R. (2015). Biomass derived low-cost microporous adsorbents for efficient $\mathrm{CO}_{2}$ capture. Fuel 148, 246-254. DOI: 10.1016/j. fuel.2015.01.032.

3. Babu, D.J., Bruns, M. \& Schneider, J.J. (2017). Unprecedented $\mathrm{CO}_{2}$ uptake in vertically aligned carbon nanotubes. Carbon 125, 327-335. DOI: 10.1016/j.carbon.2017.09.047.

4. Samanta, A., Zhao, A., Shimizu, G.K.H., Sarkar, P. \& Gupta, R. (2012). Post-combustion $\mathrm{CO}_{2}$ capture using solid
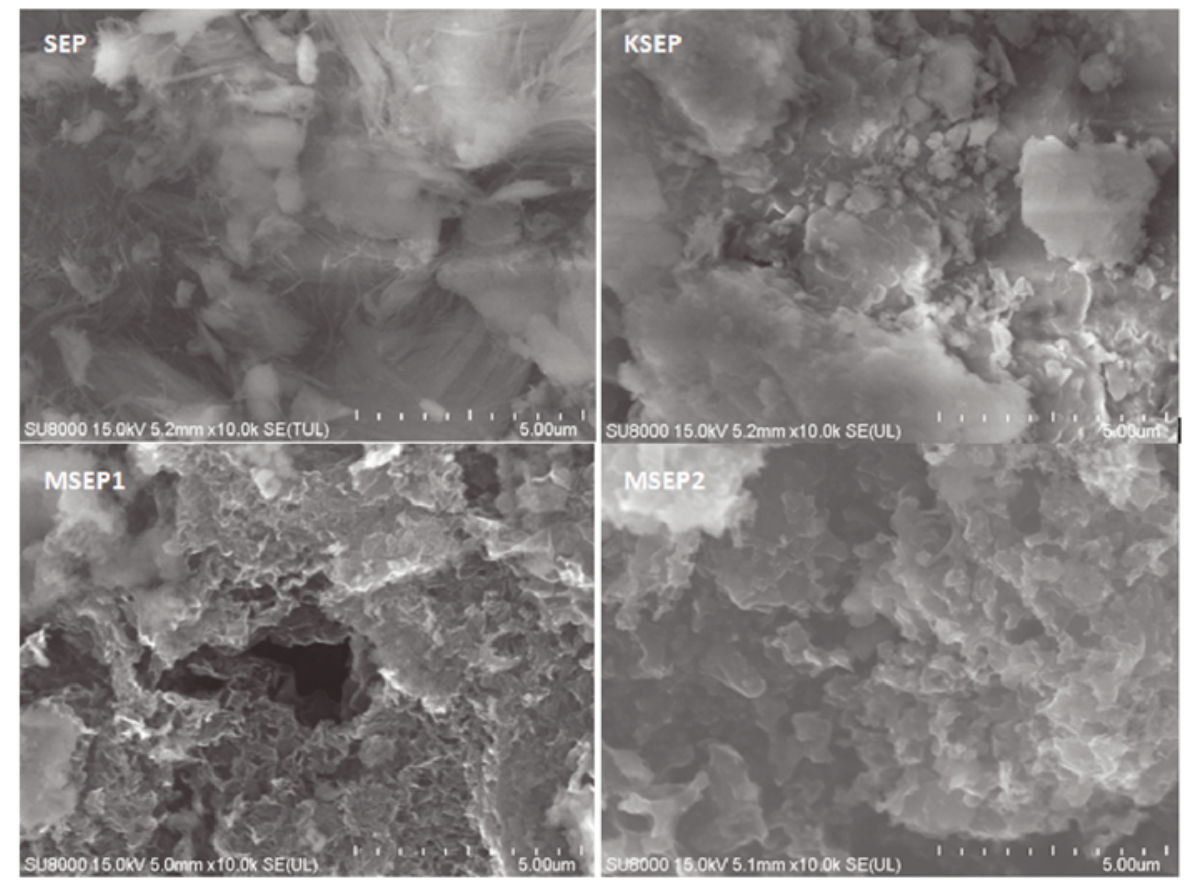

Figure 9. Scanning electron micrographs of pristine sepiolite and obtained materials 
sorbents: a review. Ind. Eng. Chem. Res. 51, 1438-1463. DOI: 10.1021/ie200686q.

5. Wang, J., Huang, L., Yang, R., Zhang, Z., Wu, J., Gao, Y., Wang, Q., O'Hare, D. \& Zhong, Z. (2014). Recent advances in solid sorbents for $\mathrm{CO}_{2}$ capture and new development trends. Energy Environ. Sci. 7, 3478-3518. DOI: 10.1039/C4EE01647E.

6. Srenscek-Nazzal, J., Narkiewicz, U., Morawski, A.W., Wrobel, R.J., Gesikiewicz-Puchalska, A. \& Michalkiewicz, B. (2016). Modification of Commercial Activated Carbons for $\mathrm{CO}_{2}$ Adsorption. Acta Phys. Pol. A 129, 394-401. DOI: 10.12693/ APhysPolA.129.394.

7. Lendzion-Bielun, Z., Czekajlo, L., Sibera, D., Moszynski, D., Srenscek-Nazzal, J., Morawski, A.W., Wrobel, R.J., Michalkiewicz, B., Arabczyk, W. \& Narkiewicz, U. (2018). Surface characteristics of $\mathrm{KOH}$-treated commercial carbons applied for $\mathrm{CO}_{2}$ adsorption. Adsorpt. Sci. Technol. 36, 478-492. DOI: $10.1177 / 0263617417704527$.

8. Gęsikiewicz-Puchalska, A., Zgrzebnicki, M., Michalkiewicz, B., Narkiewicz, U., Morawski, A.W. \& Wróbel, R.J. (2017). Improvement of $\mathrm{CO}_{2}$ uptake of activated carbons by treatment with mineral acids. Chem. Eng. J. 309, 159-171. DOI: 10.1016/j.cej.2016.10.005.

9. Zgrzebnicki, M., Krauze, N., Gęsikiewicz-Puchalska, A., Kapica-Kozar, J., Piróg, E., Jędrzejewska, A., Michalkiewicz, B., Narkiewicz, U., Morawski, A.W. \& Wróbel, R.J. (2017). Impact on $\mathrm{CO}_{2}$ Uptake of MWCNT after Acid Treatment Study. $J$. Nanomater., 1-11. DOI: 10.1155/2017/7359591.

10. Li, J.R., Kuppler, R.J. \& Zhou, H.C. (2009). Selective gas adsorption and separation in metal-organic Framework. Chem. Soc. Rev. 38, 1477-1504. DOI: 10.1039/B802426J.

11. Liu, J., Thallapally, P.K., McGrail, B.P., Brown, D.R. \& Liu, J. (2012). Progress in adsorption-based $\mathrm{CO}_{2}$ capture by metal-organic Framework. Chem. Soc. Rev. 41, 2308-2322. DOI: $10.1039 / \mathrm{C} 1 \mathrm{CS} 15221 \mathrm{~A}$.

12. Kukulka, W., Cendrowski, K., Michalkiewicz, B., \& Mijowska, E. (2019). MOF-5 derived carbon as material for $\mathrm{CO}_{2}$ absorption. Rsc. Adv. 9, 18527-18537. DOI: 10.1039/ C9RA01786K.

13. D'Alessandro, D.M., Smit, B. \& Long J.R. (2010). Carbon dioxide capture: prospects for new materials. Angew. Chem. Int. Ed. Engl. 49, 6058-6082. DOI: 10.1002/anie.201000431.

14. Marsh, H. \& Reinoso F.R. (2006). Activated Carbon. London, England: Elsevier Science.

15. Serafin, J., Narkiewicz, U., Morawski, A.W., Wróbel, R.J. \& Michalkiewicz, B. (2017). Highly microporous activated carbons from biomass for $\mathrm{CO} 2$ capture and effective micropores at different conditions. $J$. $\mathrm{CO}_{2}$ Util. 18, 73-79. DOI: 10.1016/j. jcou.2017.01.006.

16. Sreńscek-Nazzal, J., Narkiewicz, U., Morawski, A.W., Wróbel, R.J. \& Michalkiewicz, B. (2015). Comparison of Optimized Isotherm Models and Error Functions for Carbon Dioxide Adsorption on Activated Carbon. J. Chem. Eng. Data. 60, 3148-3158. DOI: 10.1021/acs.jced.5b00294.

17. Młodzik, J., Sreńscek-Nazzal, J., Narkiewicz, U., Morawski, A.W., Wróbel, R.J. \& Michalkiewicz, B. (2016). Activated Carbons from Molasses as $\mathrm{CO}_{2}$ Sorbents. Acta Phys. Pol. A. 129, 402-404. DOI: 10.12693/APhysPolA.129.402.

18. Sibera, D., Narkiewicz, U., Kapica, J., Serafin, J., Michalkiewicz, B., Wrobel, R.J. \& Morawski, A.W. Preparation and characterisation of carbon spheres for carbon dioxide capture (2019). J. Porous Mater. 26, 19-27. DOI: 10.1007/ s10934-018-0601-8.

19. Shi, X., Gong, J., Kierzek, K., Michalkiewicz, B., Zhang, S., Chu, P.K., Chen, X., Tang, T. \& Mijowska, E. (2019) Multifunctional nitrogen-doped nanoporous carbons derived from metal-organic frameworks for efficient $\mathrm{CO}_{2}$ storage and high-performance lithium-ion batteries. New J. Chem. 43, 10405-10412. DOI: doi.org/10.1039/C9NJ01542F.

20. Gong, J., Michalkiewicz, B., Chen, X., Mijowska, E., Liu, J., Jiang, Z., Wen, X. \& Tang, T. (2014). Sustainable Conver- sion of Mixed Plastics into Porous Carbon Nanosheets with High Performances in Uptake of Carbon Dioxide and Storage of Hydrogen. ASC Sustain. Chem. Eng. 2, 2837-2844. DOI: $10.1021 /$ sc500603h.

21. Melo, P., Debecker, D.P. (2019). Combining $\mathrm{CO}_{2}$ capture and catalytic conversion to methane. Waste Dispos. Sustain. Energy 1, 53-65. DOI: 10.1007/s42768-019-00004-0.

22. Taqiu Khan, M.M., Halligudi, S.B., Shukla, S. (1989). Reduction of $\mathrm{CO}_{2}$ by molecular hydrogen to formic acid and formaldehyde and their decomposition to $\mathrm{CO}$ and $\mathrm{H}_{2} \mathrm{O}$. J. Mol. Catal. 57, 47-60. DOI: 10.1016/0304-5102(89)80126-9.

23. Michalkiewicz, B., Majewska, J., Kądziołka, G., Bubacz, K., Mozia, S. \& Morawski, A.W. (2014). Reduction of $\mathrm{CO}_{2}$ by adsorption and reaction on surface of $\mathrm{TiO}_{2}$-nitrogen modified photocatalyst. J. $\mathrm{CO}_{2}$ Util. 5, 47-52. DOI: 10.1016/j. jcou.2013.12.004.

24. Solomon, S., Qin, D., Manning, M., Chen, Z., Marquis, M., Averyt, K. B., Tignor M. \& Miller H.L. (2007). Climate Change 2007: The Physical Science Basis Exit. Contribution of Working Group I to the Fourth Assessment Report of the Intergovernmental Panel on Climate Change. Cambridge, United Kingdom: Cambridge University Press.

25. Shalini, A. \& Prasad, R. (2016). An overview on dry reforming of methane: strategies to reduce carbonaceous deactivation of catalysts. $R S C A d v$. 6, 108668-108688. DOI: 10.1039/C6RA20450C.

26. Michalkiewicz, B., Sreńscek-Nazzal, J. \& Ziebro, J. (2009). Optimization of Synthesis Gas Formation in Methane Reforming with Carbon Dioxide. Catal. Lett. 129, 142-148. DOI: 10.1007/s10562-008-9797-6.

27. Michalkiewicz, B. (2004). Partial oxidation of methane to formaldehyde and methanol using molecular oxygen over Fe-ZSM-5. Appl. Catal., A. 277, 147-153. DOI: 10.1016/j. apcata.2004.09.005.

28. Michalkiewicz, B. \& Kałucki, K. (2002). Direct conversion of methane into methanol formaldehyde and organic acids. Przem. Chem. 81, 165-170.

29. Michalkiewicz, B. (2005). Kinetics of partial methane oxidation process over the Fe-ZSM-5 catalysts. Chem. Pap. Chem. Zvesti. 59, 403-408. DOI: 10.1016/j.apcata.2004.09.005

30. Michalkiewicz, B., Sreńscek-Nazzal, J., Tabero, P., Grzmil, B. \& Narkiewicz, U. (2008). Selective methane oxidation to formaldehyde using polymorphic T-, M-, and $\mathrm{H}$-forms of niobium(V) oxide as catalysts. Chem. Pap. - Chem. Zvesti. 62, 106-113. DOI: 10.2478/s11696-007-0086-4.

31. Michalkiewicz, B. (2006). The kinetics of homogeneous catalytic methane oxidation. Appl. Catal., A. 307, 270-274. DOI: 10.1016/j.apcata.2006.04.006.

32. Michalkiewicz, B., Kałucki, K. \& Sośnicki, J.G. (2003). Catalytic system containing metallic palladium in the process of methane partial oxidation. J. Catal. 215, 14-19. DOI: 10.1016/ S0021-9517(02)00088-X.

33. Michalkiewicz, B., Jarosińska, M. \& Łukasiewicz, I. (2009). Kinetic study on catalytic methane esterifi cation in oleum catalyzed by iodine. Chem. Eng. J. 154, 156-161. DOI: 10.1016/j.cej.2009.03.046.

34. Michalkiewicz, B. \& Kosowski, P. (2007). The selective catalytic oxidation of methane to methyl bisulfate at ambitne pressure. Catal. Commun. 8, 1939-1942. DOI: 10.1016/j.catcom.2007.03.014.

35. Majewska, J. \& Michalkiewicz, B. (2014). Carbon nanomaterials produced by the catalytic decomposition of methane over Ni/ZSM-5 Significance of Ni content and temperature. New Carbon Mater. 29, 102-108. DOI: 10.1016/ S1872-5805(14)60129-3.

36. Ziebro, J., Łukasiewicz, I., Borowiak-Palen, E. \& Michalkiewicz, B. (2010). Low temperature growth of carbon nanotubes from methane catalytic decomposition over nickel supported on a zeolite. Nanotechnology 21, 1-6. DOI: 10.1088/0957-4484/21/14/145308. 
37. Ziebro, J., Łukasiewicz, I., Grzmil, B., Borowiak-Palen, E. \& Michalkiewicz, B. (2009). Synthesis of nickel nanocapsules and carbon nanotubes via methane CVD. J. Alloys Compd. 485, 695-700. DOI: 10.1016/j.jallcom.2009.06.039.

38. Majewska, J. \& Michalkiewicz, B. (2016). Preparation of Carbon Nanomaterials over Ni/ZSM-5 Catalyst Using Simplex Method Algorithm. Acta Phys. Pol., A. 129, 153-157. DOI: 10.12693/APhysPolA.129.153.

39. Börjesson, P., Lantz, M., Andersson, J., Björnsson, L., Möller, B.F., Fröberg, M., Hanarp, P., Hulteberg, C., Iverfeldt, E., Lundgren, J., Röj, A., Svensson, H. \& Zinn, E. (2016). Methane as vehicle fuel - a well to wheel analysis (METDRIV). DOI: $10.13140 /$ rg.2.2.24258.79045

40. Sreńscek-Nazzal, J., Kamińska, W., Michalkiewicz, B. \& Koren, Z.C. (2013). Production, characterization and methane storage potential of $\mathrm{KOH}$-activated carbon from sugarcane molasses. Ind. Crop. Prod. 47, 153-159. DOI: 10.1016/j.indcrop.2013.03.004.

41. Wenelska, K., Michalkiewicz, B., Gong, J., Tang, T., Kaleńczuk, R., Chen, X. \& Mijowska, E. (2013). In situ deposition of Pd nanoparticles with controllable diameters in hollow carbon spheres for hydrogen storage. Int. J. Of Hydrogen Energy 38, 16179-16184. DOI: 10.1016/j.ijhydene.2013.10.008.

42. Wenelska, K., Michalkiewicz, B., Chen, X. \& Mijowska, E. (2014). Pd nanoparticles with tunable diameter deposited on carbon nanotubes with enhanced hydrogen storage capacity. Energy 75, 549-554. DOI: 10.1016/j.energy.2014.08.016.

43. Grams, J., Potrzebowska, N., Goscianska, J., Michalkiewicz, B. \& Ruppert, A.M. (2016) Mesoporous silicas as supports for Ni catalyst used in cellulose conversion to hydrogen rich gas. Int. J. Hydrogen Energy 41, 8656-8667. DOI: 10.1016/j. ijhydene.2015.12.146.

44. Młodzik, J., Wróblewska, A., Makuch, E., Wróbel, R.J. \& Michalkiewicz, B. (2016). Fe/EuroPh catalysts for limonene oxidation to 1,2-epoxylimonene, its diol, carveol, carvone and perillyl alcohol. Catal. Today 268, 111-120. DOI: 10.1016/j. cattod.2015.11.010.

45. Wróblewska, A., Makuch, E., Młodzik, J., Koren, Z.C. \& Michalkiewicz, B. (2017). Fe/Nanoporous Carbon Catalysts
Obtained from Molasses for the Limonene Oxidation Process. Catal. Lett. 147, 150-160. DOI: 10.1007/s10562-016-1910-7.

46. Wróblewska, A., Makuch, E., Młodzik, J. \& Michalkiewicz, B. (2017). Fe-carbon nanoreactors obtained from molasses as efficient catalysts for limonene oxidation. Green Process. Synth. 6, 397-401. DOI: 10.1515/gps-2016-0148.

47. Gómez-Pozuelo, G., Sanz-Pérez, E.S., Arencibia, A., Pizarro, P., Sanz, R. \& Serrano, D.P. (2019) $\mathrm{CO}_{2}$ adsorption on amine-functionalized clays. Microporous Mesoporous Mater. 282, 38-47. DOI: 10.1016/j.micromeso.2019.03.012.

48. Konuklu, Y., Ersoy, O., Akar, H.B. \& Erzin, F. (2020). Effect of pre-treatment methods on natural raw materialsbased phase change material composites for building applications. Constr. Build Mater. 263, 1-15. DOI: 10.1016/j. conbuildmat.2020.120114.

49. Ruiz-Hitzky, E., Aranda, P., Alvarez, A., Santaren, J. \& Esteban-Cubillo, A. (2011). Chapter 17 - Advanced Materials and New Applications of Sepiolite and Palygorskite. Dev. Clay Sci. 3, 393-452. DOI: 10.1016/B978-0-444-53607-5.00017-7.

50. Azzouz, A., Assaad, E., Ursu, A-V., Sajin, T., Nistor D. \& Roy, R. (2010). Carbon dioxide retention over montmorillonite-dendrimer materials. Appl. Clay Sci. 48, 133-137. DOI: 10.1016/j.clay.2009.11.021.

51. Elkhalifah, A.E.I., Bustam, M.A.B., Shariff, A.B.M. \& Murugesan, T. (2014). Carbon dioxide retention on bentonite clay adsorbents modified by mono-, Di- and triethanolamine compounds. Adv. Mater. Res. 917, 115-122. DOI: 10.4028/www. scientific.net/AMR.917.115.

52. Chen, Y.H. \& Lu, D.L. (2015). $\mathrm{CO}_{2}$ capture by kaolinite and its adsorption mechanizm. Appl. Clay Sci. 104, 221-228. DOI: 10.1016/j.clay.2014.11.036.

53. Zhou, F., Yan, C., Zhang, Y., Tan, J., Wang, H., Zhou, S. \& $\mathrm{Pu}, \mathrm{S}$. (2016). Purification and defibering of a Chinese sepiolite. Appl. Clay Sci. 124, 119-126. DOI: 10.1016/j.clay.2016.02.013.

54. Yuan, M., Gao, G., Hu, X., Luo, X., Huang, Y., Jin, B. \& Liang, Z. (2018) Premodified Sepiolite Functionalized with Triethylenetetramine as an Effective and Inexpensive Adsorbent for $\mathrm{CO}_{2}$ Capture. Ind. Eng. Chem. Res. 57, 6189-6200. DOI: 10.1021/acs.iecr.8b00348. 